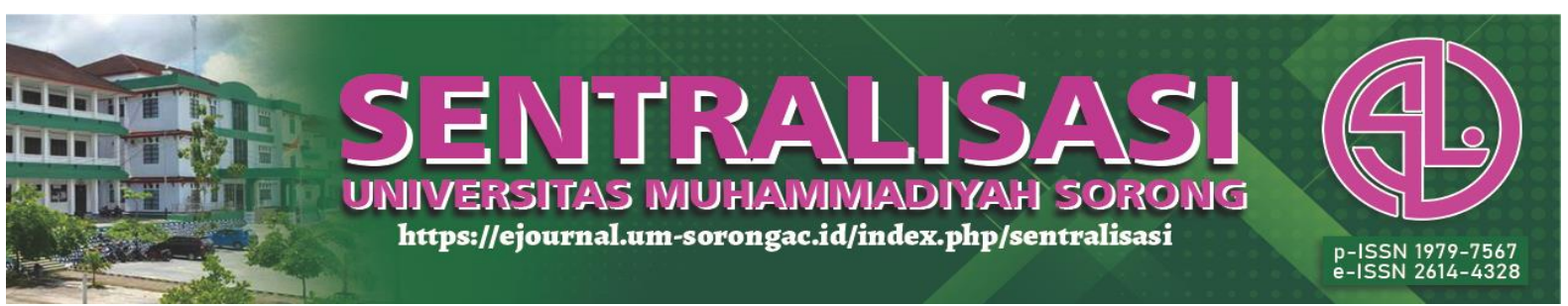

\title{
West Sumatra Education is the Leading Sector in Facing the Covid-19 Pandemic
}

\author{
Masruqi Arrazy \\ BPS-Statistics of Padang Panjang Municipality, Indonesia \\ Email : mas.ruqi@gmail.com
}

direvisi: 19/06/2021 dipublikasikan: 30/06/2021

\begin{abstract}
Abstrak. Perekonomian Sumatera Barat mengalami kontraksi ekonomi pada tahun 2020 akibat pandemi Covid-19. Akan tetapi sektor pendidikan mengalami pertumbuhan lebih baik jika dibandingkan dengan pertumbuhan nasional. Melihat hal tersebut, potensi sektor ini di Sumatera Barat perlu dianalisis sehingga bisa diketahui apakah sektor ini bisa dijadikan pilihan menjadi sektor prioritas dalam memacu pertumbuhan ekonomi Sumatera Barat untuk memasuki masa new normal. Analisis pada penelitian ini memakai data sekunder dengan metode Shift Share pendekatan klasik. Data pada penelitian ini adalah Produk Domestik Bruto Indonesia menurut Harga Konstan dan Produk Domestik Regional Bruto Sumatera Barat menurut Harga Konstan dengan periode data tahun 2019 dan 2020. Dari hasil analisis diketahui sektor pendidikan bertumbuh dengan progresif. Sektor ini di Sumatera Barat bertumbuh lebih cepat dibanding dengan nasional dan daya saingnya lebih baik dibanding sektor lain yang ada di Sumatera Barat. Hal lainnya menurut penelitian ini adalah sektor pendidikan bisa mempengaruhi beberapa sektor lainnya di masa pandemi. Sehingga sektor ini sangat layak dijadikan sektor unggulan dalam menghadapi situasi new normal.
\end{abstract}

Kata kunci: Efek Pengganda, Kontraksi Ekonomi, Pergeseran Bersih, Pertumbuhan Proposional, Pertumbuhan Pangsa Wilayah

Abstract. The economy of West Sumatra experienced an economic contraction in 2020 due to the Covid-19 pandemic. However, the education sector experienced better growth compared to national growth. Seeing this, the potential of this sector in West Sumatra needs to be analyzed so that it can be seen whether this sector can be chosen as a priority sector in spurring West Sumatra's economic growth to enter the new normal period. The analysis in this study uses secondary data with the classic Shift Share method. The data in this study are Indonesia's Gross Domestic Product according to Constant Prices and the Gross Regional Domestic Product of West Sumatra according to Constant Prices with the 2019 and 2020 data periods. From the analysis results, it is known that the education sector is growing progressively. This sector in West Sumatra is growing faster than the national one and its competitiveness is better than other sectors in West Sumatra. Another thing according to this research is that the education sector can affect several other sectors during the pandemic. So that this sector is very worthy of being the leading sector in dealing with the new normal situation.

Keywords: Multiplier Effect, Economic Contraction, Net Shift, Proportional Growth, Regional Share Growth 




\section{Introduction}

The Covid-19 pandemic causes economic instability due to a decline in economic activity in a region (Burhanuddin and Abdi 2020; Hadiwardoyo 2020). As a result, the Province of West Sumatra is also affected by experiencing an economic slowdown. The economic growth of West Sumatra Province in 2020 also experienced a contraction (minus growth) of 1.60 percent (BPS Sumbar 2021). The economic contraction in this province is better than the economic contraction in Indonesia. West Sumatra experienced a contraction of 1.44 percent in 2020 (BPS Sumbar 2021). The contraction in West Sumatra Province was lower than the contraction experienced nationally. The reason is due to differences in contraction in several business sectors in West Sumatra and Indonesia.

This difference is caused by differences in goods and services consumed by the people of West Sumatra Province compared to Indonesian society in general (Hutabarat 2020; Jumiyanti and Yusuf 2020; Nuraini 2017). The West Sumatra Regional Government can determine which sectors will be prioritized to be the main drivers of the province's economic growth because of these differences (Diana, Sulistiowati, and Hadi 2017; Mujiraharjo and Basuki 2017; Suarmanayasa, Susila, and Bagia 2018; Yunan 2011). This makes it easier for the local government to design scenarios so that economic growth is as expected (Mukhamad and Harefa 2020; Setiyawan 2019)

In 2020, the West Sumatran economy is still very dependent on the agricultural sector (Badan Pusat Statistik Provinsi Sumatera Barat 2021). The contribution of the agricultural sector is quite large, which is 22.38 percent. However, this sector has not been able to become a sector with the main priority in West Sumatra because the growth of the Agriculture sector (Agriculture, Forestry and Fisheries) in West Sumatra is lower than the national growth.

The sector with higher growth than national in this province is the Education Sector. The growth of this sector in West Sumatra reached 5.91. This figure is very high when compared to the growth of this sector nationally. Even Jogjakarta, which is an education city (Zubaidah et al. 2016) has a lower growth rate in 2020. This sector actually has a good history in West Sumatra. Many educational institutions were established before the independence of the Republic of Indonesia such as Dinniyah, Thawalib, Muhammadiyah (Rahman 2015; 


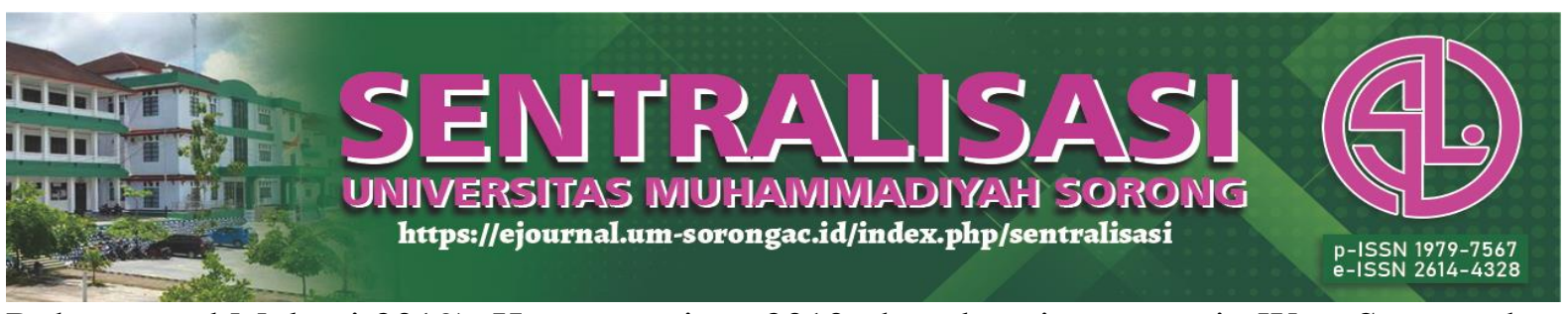

Rohman and Mulyati 2019). However, since 2010, the education sector in West Sumatra has contributed never more than five percent of the economy of West Sumatra (BPS Sumbar 2021)

Seeing the high growth of the education sector in West Sumatra, it is necessary to study whether this sector has the potential to be a leading sector by the West Sumatra government during the pandemic that still hit West Sumatra Province. One of the analytical methods that can see this potential is the Shift Share Method (Classical Approach). This analysis can provide an overview of changes in economic structure that occur in certain areas and provide a more accurate picture of economic growth and changes in economic structure in that area. So it can see the potential of the sector in the province of West Sumatra, especially the Education sector (Hajeri, Yurisinthae, and Dolorosa 2015; Setiyawan 2019; Tristanto 2013; Yunus et al. 2020)

Some of the factors that showed excellence in the education sector will do the research to analyze the potential of the sector in West Sumatra Province by comparing and looking at the relationship between the education sector and other sectors in West Sumatra. The main purpose of this study is to see the potential that exists in the education sector so that it can be seen whether this sector is worthy of consideration by the government of West Sumatra as a priority sector in helping spur economic development in the new normal.

\section{Research Methods}

This type of research is quantitative research using secondary data as the main source of research. Secondary data comes from publications published by BPS RI and BPS West Sumatra Province. The variables used are Indonesia's Gross Domestic Product at constant prices and West Sumatra's Gross Regional Domestic Product according to Constant Prices with data periods in 2019 and 2020. The data used is only two years because it sees changes from 2019 to 2020. The year 2020 is the beginning of the Covid pandemic. -19 happened. GDP and GRDP data are divided into 17 sectors which are adjusted to 17 business fields in the publication. The technical analysis used is the method with the Shift-Share Classical Approach.

\section{Shift Share Method Classical Approach}

Adão et al. (2018) said that this method is one of the techniques in analyzing regional data, by looking at the structure of the regional economy and its changes. This is done by 
focusing on sector growth in a region and projecting economic activity in the region even though the data analysed is limited (Islamy 2019; Priyarsono and Sahara 2007).

This analysis has three components to divide the economic growth of a region, namely National Growth (PN), Proportional Growth (PP) and Regional Share Growth (PPW). National Growth (PN) is a change in production in a certain area due to changes in production, national economic policies, and other policies that are able to affect the economic sector in a region. Proportional Growth (PP) is a change in production in a particular area due to the sector composition in demand for final products and differences in market structure and diversity. Regional Share Growth (PPW) is a change in production in a certain area caused by a comparative advantage in that region. The model of Shift Share is as follows:

$$
P E_{i j}=P N_{i j}+P P_{i j}+P P W_{i j}
$$

So that each component can be described by:

$$
\begin{gathered}
P N_{i j}=R_{a}+Y_{i j} \ldots \ldots \\
P P_{i j}=\left(R_{i}-R_{a}\right) Y_{i j} \\
P P W_{i j}=\left(r_{i}-R_{i}\right) Y_{i j}
\end{gathered}
$$

Where $R_{a}, R_{i}$ dan $r_{i}$ represent provincial and national growth rate and can be defined as follows:

$$
\begin{aligned}
& R_{a}=\left(Y_{t}-Y_{o}\right) / Y_{o} \\
& R_{i}=\left(Y_{i t}-Y_{i o}\right) / Y_{i o} \\
& r_{i}=\left(y_{i t}-y_{i o}\right) / y_{i o}
\end{aligned}
$$

Components of PP and PPW are added up, it will be PB. PB can be used to identify the growth of a sector of the economy. The PB of a particular sector in region $\mathrm{j}$ can be formulated as follows:

$$
P B_{i j}=P P_{i j}+P P W_{i j}
$$




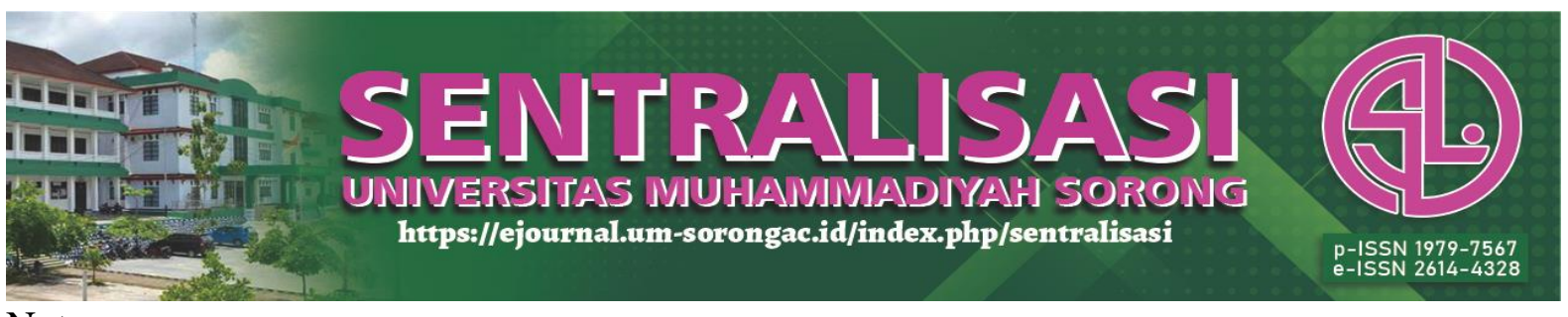

Note:

$P E_{i j} \quad$ : Economic growth for sector $i$ in West Sumatra Province (j)

$P N_{i j} \quad$ : National Growth for sector $i$ in West Sumatra Province (j)

$P P_{i j} \quad$ : Proportional Growth for sector $i$ in West Sumatra Province (j)

$P P W_{i j}$ : Regional Share Growth for sector $i$ in West Sumatra Province (j)

$P B_{i j} \quad$ : Net Shift for sector $i$ in West Sumatra Province (j)

$R_{a} \quad$ : Total ratio in national territory

$R_{i} \quad:$ Ratio of Sector $i$ in the national territory

$r_{i} \quad:$ Ratio of Sector $i$ in the regional territory

$Y_{t} \quad$ : National economic growth rate in year $t$

$Y_{o} \quad$ : National economic growth rate in year $o$

$Y_{i t} \quad$ : National economic growth rate for sector $i$ in year $t$

$Y_{i o} \quad$ : National economic growth rate for sector $i$ in year $o$

$y_{i t} \quad$ : Regional economic growth rate for sector $i$ in year $t$

$y_{i o} \quad$ : Regional economic growth rate for sector $i$ in year $o$

$t \quad: 2020$

o : 2019

The profile of a particular sector in an area can be seen from the value of national growth and the growth of regional share. If the Proportional Growth (PP) of a particular sector is positive, then the growth of that sector is faster than national growth and vice versa. Meanwhile, a positive Regional Share Growth (PPW) means that the competitiveness of this sector is better than the competitiveness of other sectors in the same region. Proportional Growth and Regional Share Growth if juxtaposed, these sectors can be grouped into four categories. These categories are represented in one quadrant which can be seen in table 1. (Salakory and Matulessy 2020)

Table 1. Sector Category Based on PP and PPW

\begin{tabular}{cccc}
\hline Quadrant & PP & PPW & Information \\
\hline I & + & + & Fast Growth and Good Competitiveness \\
II & + & - & Fast Growth and Poor Competitiveness \\
III & - & - & Slow Growth and Poor Competitiveness \\
IV & - & + & Slow Growth and Good Competitiveness \\
\hline
\end{tabular}

Sumber : (Priyarsono and Sahara 2007)

Net Shift Component (PB) can see the growth profile of certain sectors in the West Sumatra region. When $\mathrm{PB}$ is positive, it shows that growth in the sector is progressive (growth 
is accelerating more than other sectors in the region). If PB is negative, it indicates slowing growth compared to other sectors.

\section{Results and Discussion}

EconomicWest Sumatra has shown an economic decline reaching minus 1.60 percent in 2020. However, this value is slightly better when compared to national conditions. This illustrates the economic condition of West Sumatra which is better than the condition of Indonesia in general. This condition was supported by the presence of several sectors that experienced positive growth conditions. In total there are six sectors with positive growth. Three of these sectors experienced positive growth with a value of five percent in the Information \& Communication (Infokom) sector; Health Services \& Social Activities (Health Services) and Education Services.

The Infocom sector is experiencing growth due to the transformation in the world of education and work that has forced activities that were originally face-to-face to be online (Herliandry, N. Nurhasanah, et al. 2020). The sector with the second highest growth is Health Services. This is very reasonable because the government's focus is on this sector, for example intensively on health workers (Aji 2020). Meanwhile, the education sector, which was feared that the online transformation would have a bad impact, turned out to continue to grow during the pandemic (Herliandry, N. Nurhasanah, et al. 2020).

Table 2. Results of West Sumatra Shift Share Analysis

\begin{tabular}{lcccc}
\hline \multicolumn{1}{c}{ Sector } & PB & PP & PPW & Quadrant \\
\hline Agriculture, Forestry and Fisheries & 2,77 & 3,33 & $-0,56$ & II \\
Mining and Quarrying & 0,28 & $-0,37$ & 0,65 & IV \\
Processing Industry & 1,04 & $-1,35$ & 2,39 & IV \\
Electricity and Gas Procurement & $-5,22$ & $-0,76$ & $-4,46$ & III \\
Water Supply, Waste Management, Waste & & & & \\
Management and Recycling & 0,30 & 6,52 & $-6,21$ & II \\
Construction & $-1,34$ & $-1,67$ & 0,33 & IV \\
& & & & \\
\hline
\end{tabular}




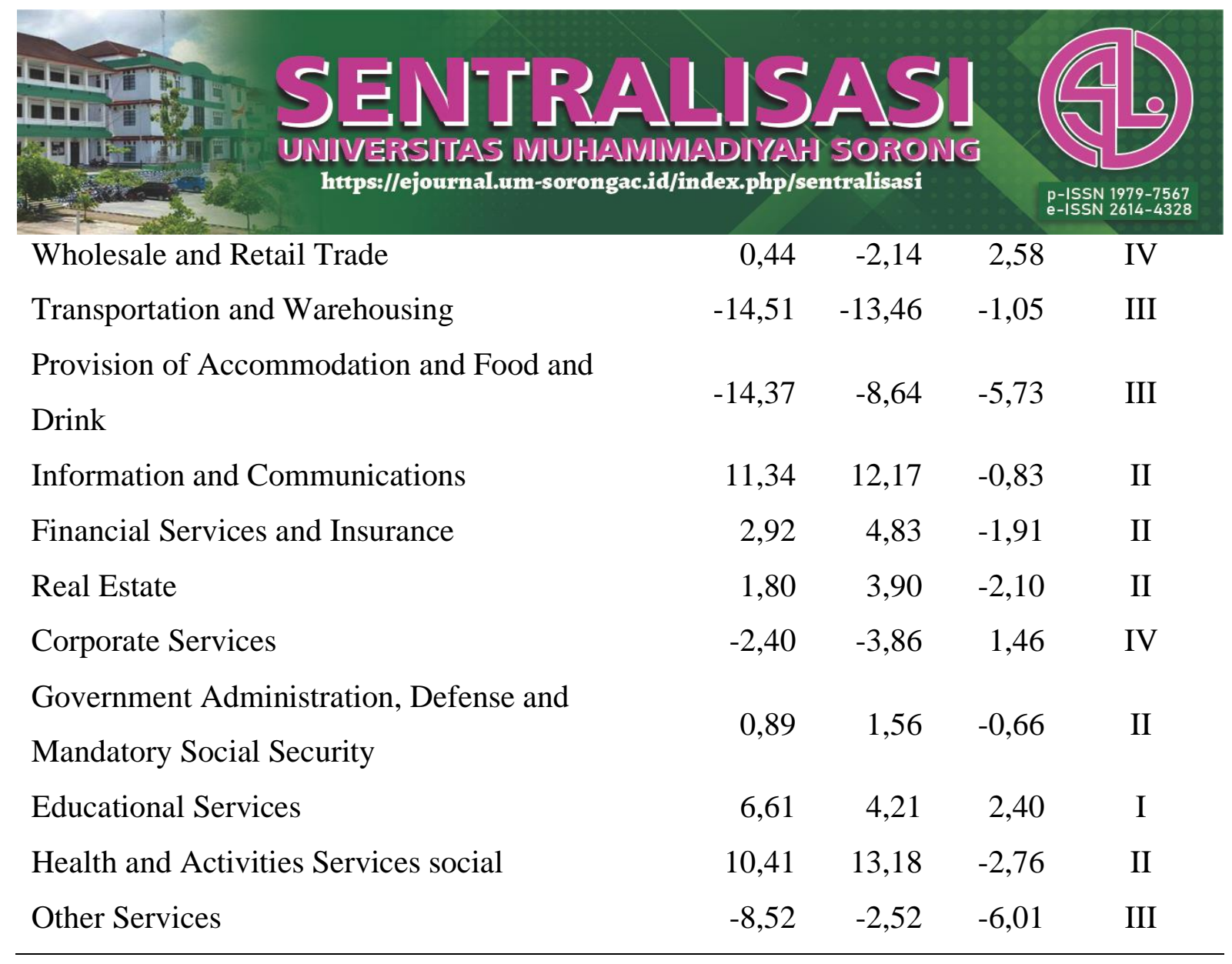

Source : BPS Statistics of Sumatera Barat Province (processed data)

The results of the shift share analysis based on the PB value show that there are 11 sectors that are experiencing progressive development and six sectors of slow development. The sectors that experienced the highest progressive development were the Information and Communications Sector, the Health Sector and the Education Sector. Meanwhile, the sectors that experienced the slowest development were the Transportation and Warehousing Sector, the Accommodation and Food and Drink Provision Sector and the Other Services Sector. In general, the Net Shift has a pattern similar to the rate of economic growth.

Another analysis result is that based on the grouping based on PP and PPW there is one sector in quadrant I, seven sectors in quadrant II, four sectors in quadrant III and five sectors in quadrant IV. One sector in quadrant I is the education sector. This sector in West Sumatra is the only sector that has a positive value in PP and PPW. This indicates that this sector is growing faster than the growth of the same sector nationally and has better competitiveness than other sectors in West Sumatra. This contradicts the general idea that the Education Sector is experiencing a decline due to a significant transformation due to the Covid-19 pandemic (Herliandry, Nurhasanah, et al. 2020). 


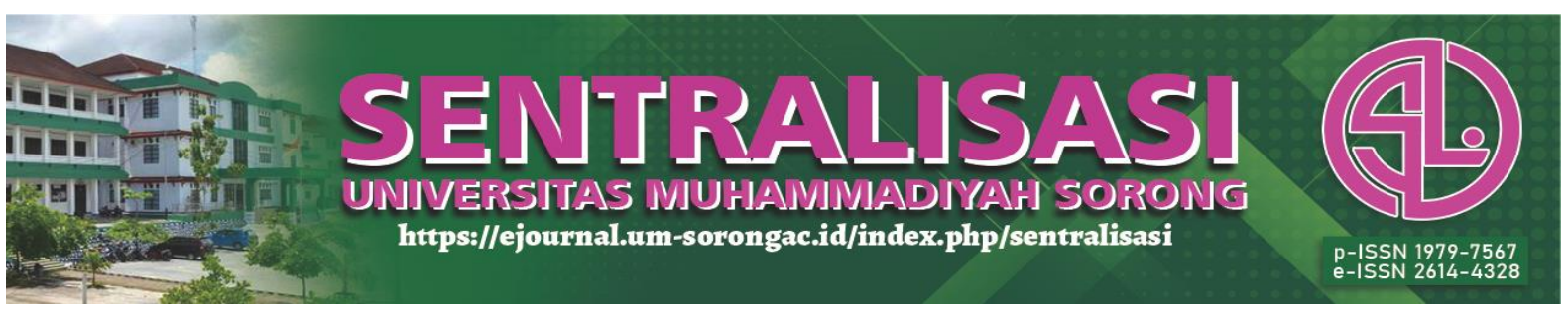

The education sector in West Sumatra is a sector that is always growing when viewed from 2010, but the contribution of this sector to the economy is quite small and its contribution tends to stagnate with a value that never exceeds five percent (BPS Sumbar 2021). However, this sector during the pandemic is progressive. The main cause is online educational activities. This causes the activities to be carried out in the West Sumatra area, but the students are in their respective residences. So that this sector is still operating as usual even though there is a transformation in the way of learning or other things.

Another interesting thing about this sector is the influence (positive or negative) on other sectors. The Information and Communications Sector is a sector that has been positively impacted by the Education Sector. This sector is the sector with the highest growth rate in West Sumatra in pandemic (BPS Sumbar 2021). This is due to the need for information technology and internet networks to connect between teachers and students so that the teaching and learning process continues (Pakpahan and Fitriani 2020).

Government policies that make this sector undergo a transformation of the way of learning also cause negative multiplier effects in some sectors. The sector experienced a contraction during the pandemic due to a decrease in activity due to the absence of students in the West Sumatra region. This is because many of these students come from outside the region (Dwita 2016). This causes the economic activity to not run in some of these sectors. The sectors affected include the accommodation sector and the transportation sector. These two sectors are the sectors that experienced the deepest contraction in West Sumatra Province.

The Real Estate Sector also gets a negative effect from the education sector. This sector continued to grow during the pandemic but the growth of this sector decreased significantly when compared to the previous year. In addition, this sector is in quadrant II. This sector has a positive PP value and a negative PPW value. The PP value is positive so it can be concluded that the growth is better than the national one. While the PPW value is negative, it means that this sector has less competitiveness when compared to other sectors in West Sumatra. The education sector plays a very important role in this sector, especially at the university level (Toisuta 2018). From this it can be concluded that this sector continues to grow because the influence of the growth of the education sector in West Sumatra is better than national 


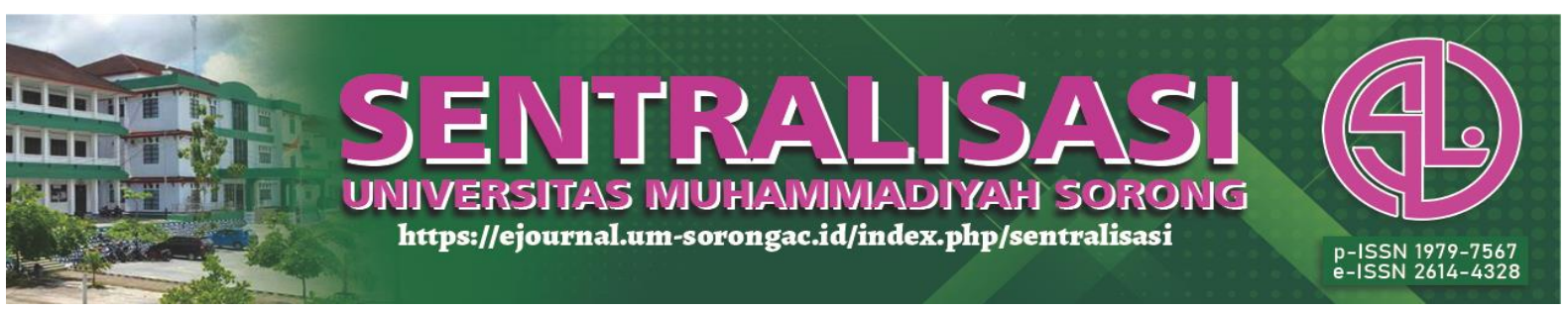

conditions. However, the low competitiveness of this sector compared to other sectors is caused by the absence of some economic activities because students (both school and university levels) who are consumers in this sector are not in the education area (Prasdika, Auliyah, and Setiawan 2018).

The education sector has great potential to become the leading sector of the West Sumatra government in dealing with the new normal situation. According to this study, the Education Sector is more promising than Tourism, which was a priority for West Sumatra before the pandemic (Endah and Almegi 2016). In addition, there is a multiplier effect from this sector causing negative or positive effects that affect the development of other sectors in West Sumatra. If the government can carry out the right policies, the multiplier effect can be the optimal impact on West Sumatra's economic growth.

\section{Conclusion}

The Covid-19 pandemic caused an economic contraction in West Sumatra. Judging from the results of the analysis in this study, the Education Sector has many advantages so that this sector is quite resilient in the face of the Covid-19 pandemic. This makes the main point that is the reason this sector deserves to be the main sector for the West Sumatra Provincial government in moving the economy in a new normal situation. The next point is that the multiplier effect of this sector can make significant changes to other sectors. From this research, it can be seen that this sector has advantages compared to other sectors in West Sumatra. From this research it can be concluded that this sector is very feasible to be used as a leading sector in the face of the new normal policies that have been implemented in West Sumatra.

Furthermore, it is necessary to study more deeply about the multiplier effect of the Education sector on other sectors. In this study, we have not been able to see the description of correlations, relationships and inter-sectoral linkages in West Sumatra. This is a limitation of Shift Share Analysis. 


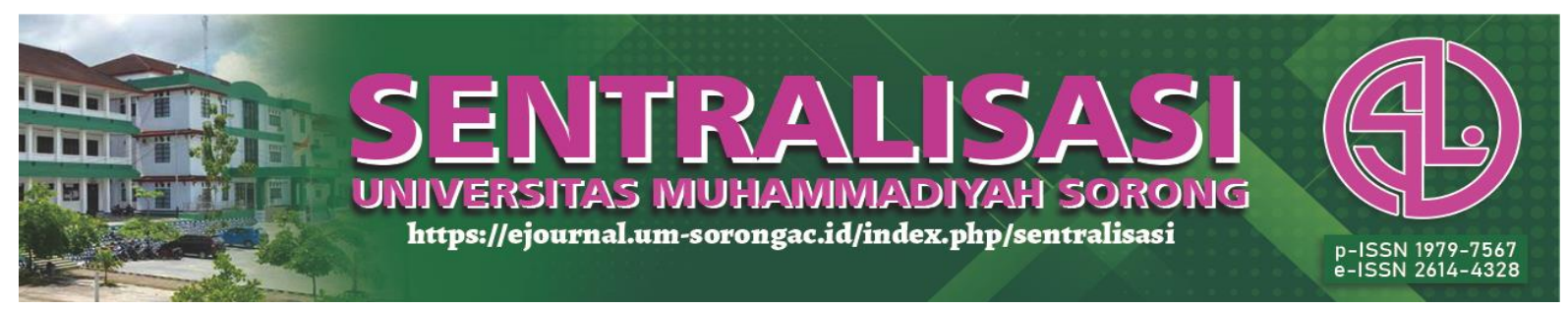

\section{Reference}

\section{Journal}

Abidin, Zainal. 2015. "Aplikasi Analisis Shift Share Pada Transformasi Sektor Pertanian Dalam Perekonomian Wilayah Di Sulawesi Tenggara." Jurnal Informatika Pertanian 24(2):165-78.

Adão, Rodrigo, Michal Kolesár, and Eduardo Morales. 2018. "Shift-Share Designs: Theory and Inference." Growth and Change 19(2):1-10. doi: 10.2139/ssrn.3236471.

Aji, Irawan Purwo. 2020. “Tinjauan Insentif PPh Bagi SDM Di Bidang Kesehatan Dalam Masa Pandemi Virus CoVID-19." Behavioral Accounting Journal 3(2):159-71. doi: 10.33005/baj.v3i2.105.

Burhanuddin, Chairul Iksan, and Muhammad Nur Abdi. 2020. "Ancaman Krisis Ekonomi Global Dari Dampak Penyebaran Virus Corona (COVID-19)." AkMen 17(1):90-98. doi: https://doi.org/10.37476/akmen.v17i1.866.

Diana, Marisa, Dwi Sulistiowati, and Syamsul Hadi. 2017. "Analisis Sektor Ekonomi Unggulan Di Provinsi Maluku Utara.” Jurnal Ilmu Ekonomi 1(4):400-415.

Dwita, Hanifa. 2016. "Perancangan Sistem Informasi Untuk Pencarian Rumah Kos Bagi Mahasiswa Universitas Andalas.” Universitas Andalas.

Endah, Purwaningsi, and Almegi. 2016. "Pengembangan Pariwisata Maritim Berbasis Masyarakat (Community Based Management) Di Kawasan Mandeh Sumatera Barat." Jurnal Geografi 5(1):20-28.

Hadiwardoyo, Wibowo. 2020. "Kerugian Ekonomi Nasional Akibat Pandemi Covid-19 [National Economic Losses Due to the Covid-19 Pandemic]." Baskara Journal of Business and Enterpreneurship 2(2):83-92. doi: 10.24853/baskara.2.2.83-92.

Hajeri, Hajeri, Erlinda Yurisinthae, and Eva Dolorosa. 2015. "Analisis Penentuan Sektor Unggulan Perekonomian Di Kabupaten Kubu Raya." Jurnal Ekonomi Bisnis Dan Kewirausahaan 4(2):253. doi: 10.26418/jebik.v4i2.12485.

Herliandry, Luh Devi, Nurhasanah Nurhasanah, Maria Enjelina Suban, and Heru Kuswanto. 2020. "Pembelajaran Pada Masa Pandemi Covid-19." JTP - Jurnal Teknologi Pendidikan 22(1):65-70. doi: 10.21009/jtp.v22i1.15286.

Herliandry, Luh Devi, Nurhasanah, Maria Enjelina Suban, and Kuswanto Heru. 2020. "Transformasi Media Pembelajaran Pada Masa Pandemi Covid-19." Jurnal Teknologi Pendidikan 22(1):65-70.

Hutabarat, Ruth Yuliani. 2020. "Penentuan Sektor Unggulan Di Kabupaten Kepulauan Anambas." Jurnal Samudra Ekonomi Dan Bisnis 11(1):95-110. doi: 10.33059/jseb.v11i1.1790.

Islamy, Nurul. 2019. “Analisis Sektor Potensial, Dapatkah Pariwisata Menjadi Lokomotif Baru 


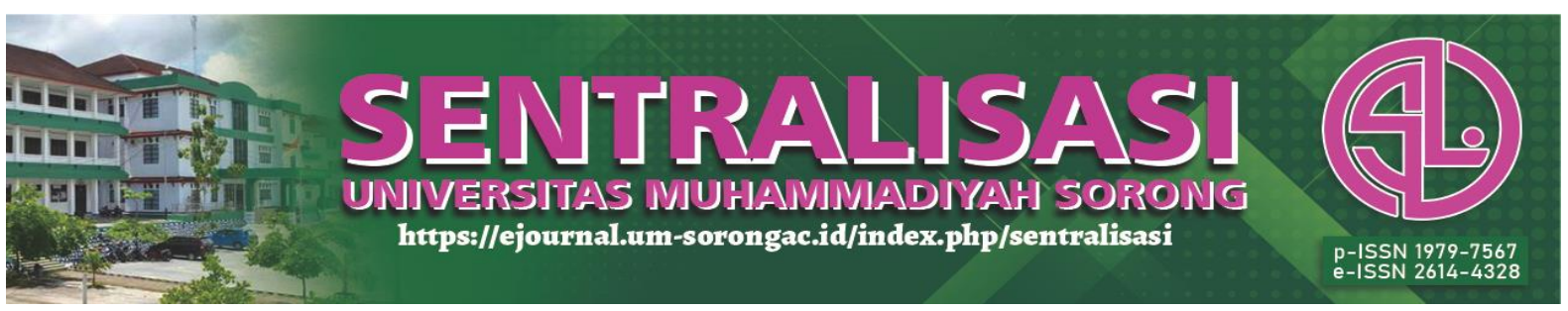

Ekonomi Nusa Tenggara Barat?" Journal of Indonesian Tourism, Hospitality and Recreation 2(1):1-10. doi: 10.17509/jithor.v2i1.16426.

Jumiyanti, Kalzum R., and Barmin R. Yusuf. 2020. "Pola Pengembangan Potensi Daerah Dalam Upaya Peningkatan Produk Domestik Regional Bruto Provinsi Gorontalo." Sentralisasi 9(1):36-44. doi: doi.org/10.33506/sl.v9i1.569.

Mujiraharjo, Febri, and Mahmud Nugroho Basuki. 2017. "Analisis Sektor Unggulan Kabupaten Sleman Dengan Metode Shift Share Dan Location Quotient." Jurnal Sains, Teknologi Dan Industri 15(1):52-60. doi: 10.4103/2276-7096.188531.

Mukhamad, Burhanudin Faturahman, and Mandala Harefa. 2020. "Upaya Pemerintah Dalam Mengantisipasi Perlambatan Pertumbuhan Ekonomi 2020.” INFO Singkat 12(10):19-23.

Nuraini, Ida. 2017. "Kualitas Pertumbuhan Ekonomi Daerah Kabupaten / Kota Di Jawa Timur.” Jurnal Ekonomi Pembangunan Vol. 15:79-93.

Pakpahan, Roida, and Yuni Fitriani. 2020. “Analisa Pemafaatan Teknologi Informasi Dalam Pemeblajaran Jarak Jauh Di Tengah Pandemi Virus Corona Covid-19." JISAMAR (Journal of Information System, Applied, Management, Accounting and Researh) 4(2):30-36.

Prasdika, Danang, Robiatul Auliyah, and Achdiar Redy Setiawan. 2018. "Menguak Nilai Dan Makna Di Balik Praktik Penentuan Harga Sewa: Studi Fenomenologis Pada Pengusaha Kos-Kosan.” Jurnal InFestasi 14(1):40-56. doi: 10.21107/infestasi.v14i1.4259.

Rahman, Rini. 2015. "MODERNISASI PENDIDIKAN ISLAM AWAL ABAD 20 (Studi Kasus Di Sumatera Barat).” Humanus 14(2):174. doi: 10.24036/jh.v14i2.5684.

Rohman, Fandy Aprianto, and Mulyati Mulyati. 2019. "Rintisan Awal Pendidikan Muhammadiyah Di Sumatera Barat Tahun 1925-1939." Jurnal Penelitian Sejarah Dan Budaya 5(1):23-41. doi: 10.36424/jpsb.v5i1.20.

Salakory, Hans Sammy Marthin, and Febby Sonya Matulessy. 2020. "Analisis Shift-Share Terhadap Perekonomian Kota Sorong." BAREKENG: Jurnal Ilmu Matematika Dan Terapan 14(4):575-86. doi: 10.30598/barekengvol14iss4pp575-586.

Setiyawan, Arbi. 2019. “Analisis Sektor Perekonomian Basis Dan Progresif Di Kabupaten Bogor.” Akuntabel 16(2):2019-2158.

Suarmanayasa, I. Nengah, Gede Putu Agus Jana Susila, and I. Wayan Bagia. 2018. "Determination of Potential Economic Sectors to Support Economic Development Planning." Pp. 69-74 in 3rd International Conference on Tourism, Economics, Accounting, Management, and Social Science (TEAMS 2018). Vol. 69.

Toisuta, Jondri Josias. 2018. "Pengaruh Lingkungan Kos-Kosan Terhadap Motivasi Belajar Mahasiswa Stakpn Ambon.” INSTITUTIO: Jurnal Pendidikan Agama Kristen IV(II).

Tristanto, Afrendi Hari. 2013. "Analisis Sektor Ekonomi Unggulan Dalam Pengembangan Potensi Perekonomian Di Kota Blitar.” Jurnal Ilmiah Mahasiswa FEB 1(2):1-30. 


\section{SENITRALISAS}

UNIVERSITAS IVIURAMUIVIADIYAH SORONG

httpss//ejournal.um-sorongac.id/index.php/sentralisasi

Yunan, Zuhairan Yunmi. 2011. "Analisis Sektor Unggulan Kota Bandar Lampung (Sebuah Pendekatan Sektor Pembentuk PDRB)." in Seminas Competitive Advantage I.

Yunus, Siswono Rahmat, Nurdin Lanuhu, Pipi Diansari, Muh Hatta Jamil, and Muhammad Arsyad. 2020. "ANALISIS SEKTOR PROGRESIF DAN KOMODITI BASIS PERTANIAN DI KABUPATEN BOLAANG MONGONDOW , PROVINSI SULAWESI UTARA Analysis of Progressive Sectors and Agricultural Base Commodities in Bolaang Mongondow Regency, North Sulawesi Province Abstrak Pembangunan Da." 16(2):161-74.

Zubaidah, Enny, Poerwanti Hadi Pratiwi, Siti Hamidah, and Ali Mustadi. 2016. "Migrasi Pelajar Dan Mahasiswa Pendatang Di Kota Pendidikan.” Pp. 597-608 in Prosiding Seminar Nasional.

\section{Book}

Priyarsono, DS, and S. P. Sahara. 2007. "Dasar Ilmu Ekonomi Regional.” Modul Ekonomi Regional.

\section{Publication}

Badan Pusat Statistik Provinsi Sumatera Barat. 2021. Pertumbuhan Ekonomi Sumatera Barat Triwulan $I V-2020$.

BPS Sumbar. 2021. Distribusi Produk Domestik Regional Bruto Provinsi Sumatera Barat Atas Harga Berlaku Menurut Lapangan Usaha (Triwulanan) (Persen). 